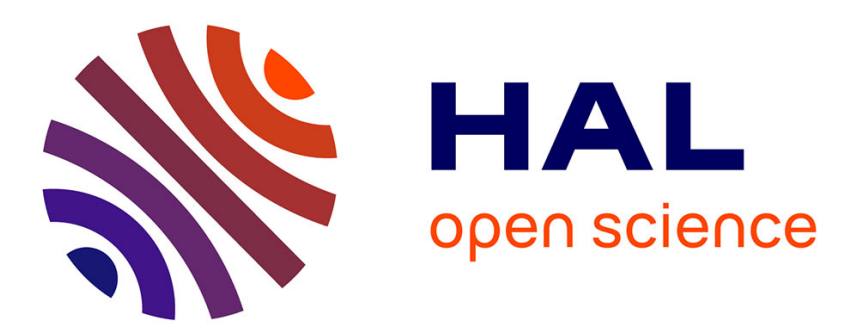

\title{
Selectivity and efficiency of the acido-soluble extraction in sequential extraction procedure
}

Lydia Leleyter, Fabienne Baraud

\section{To cite this version:}

Lydia Leleyter, Fabienne Baraud. Selectivity and efficiency of the acido-soluble extraction in sequential extraction procedure. International Journal of Soil Science, 2006, 1 (2), pp.168-170. hal-02632895

\section{HAL Id: hal-02632895}

\section{https://hal-normandie-univ.archives-ouvertes.fr/hal-02632895}

Submitted on 26 Jun 2020

HAL is a multi-disciplinary open access archive for the deposit and dissemination of scientific research documents, whether they are published or not. The documents may come from teaching and research institutions in France or abroad, or from public or private research centers.
L'archive ouverte pluridisciplinaire HAL, est destinée au dépôt et à la diffusion de documents scientifiques de niveau recherche, publiés ou non, émanant des établissements d'enseignement et de recherche français ou étrangers, des laboratoires publics ou privés. 


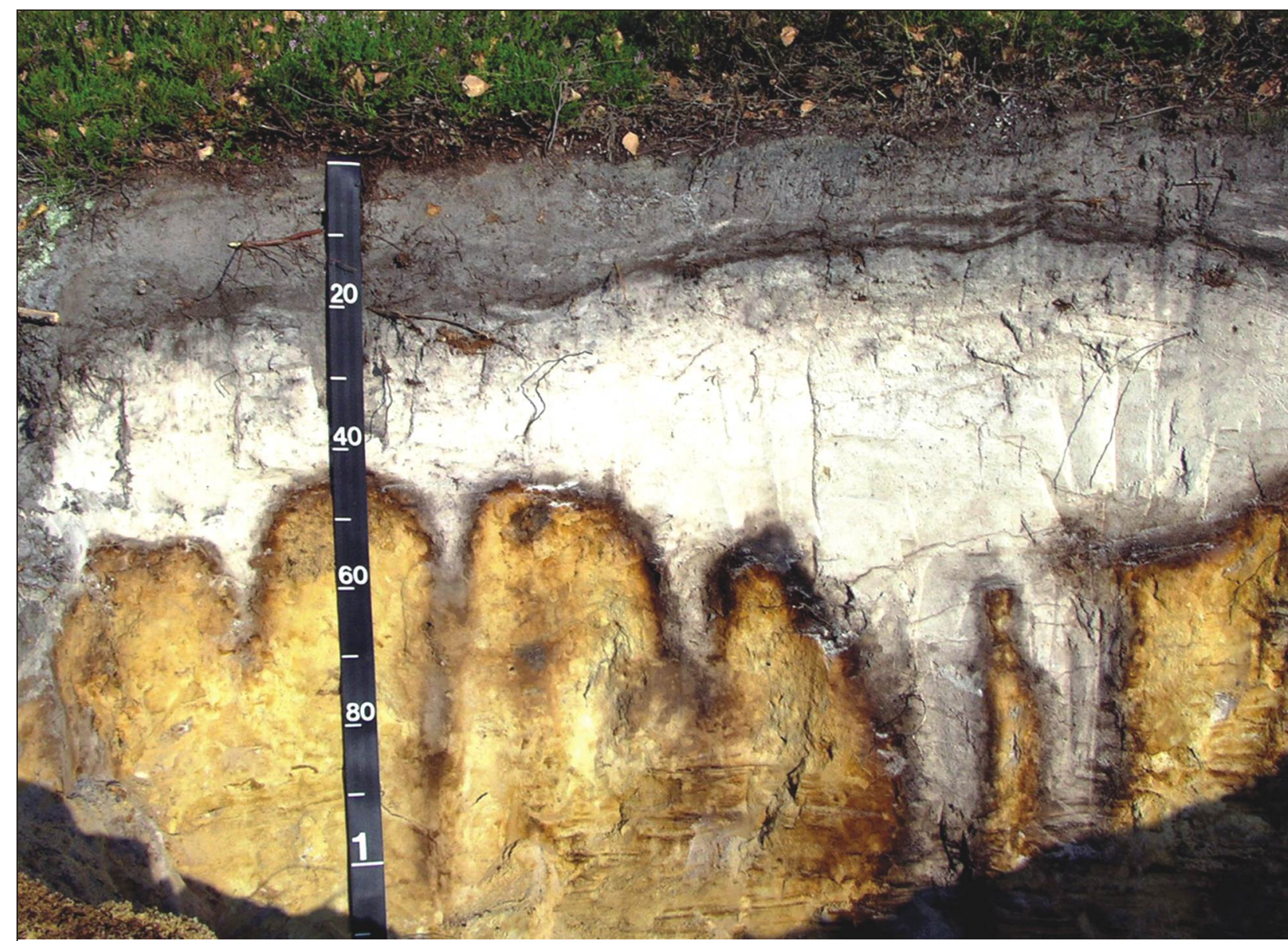

\section{International Journal of Soil Science}

ISSN 1816-4978

\section{(a)}

Academic

Journals Inc. 
International Journal of Soil Science 1 (2): 168-170, 2006

ISSN 1816-4978

(C) 2006 Academic Journals Inc., USA

\title{
Selectivity and Efficiency of the Acido-soluble Extraction in Sequential Extraction Procedure
}

\author{
Leleyter Lydia and Baraud Fabienne \\ Equipe de Recherche en Physico-Chimie et Biotechnologie (ERPCB)- \\ IUT-UFR de Sciences, Université de Caen-EA 3914-Campus 2, \\ Sciences 2 Boulevard du Maréchal Juin-14032 CAEN, France
}

\begin{abstract}
In order to estimate heavy metals partitioning in soil or sediments, to evaluate their mobility and so their bioavailability, a 7-steps sequential chemical extraction procedure had been developed. But as the efficiency and selectivity of the acido-soluble extraction was now controversed, the objective of this complementary study was to show that this fraction is actually essentially composed of carbonates (as calcite or dolomite), but phosphates (as apatites) are few solubilized during this extraction step.
\end{abstract}

Key words: Chemical extraction procedure, apatite, efficiency

\section{Introduction}

Sequential extraction procedures, which are expensive and time consuming, have the advantage of characterizing the different labile fractions. So, they are one of the most useful tools for solid speciation of particulate elements, to study the origin, the fate, the biological and physicochemical availability and transport of sorbed elements (Gaiero et al., 2003; Da Silva et al., 2002; Leleyter and Probst, 1999; Ma and Uren, 1998; Baruah et al., 1996; Lebourg et al., 1996; Ure et al., 1995; Shuman, 1985; Tessier et al., 1979). The elements present in the exchangeable fraction are weakly bound and in equilibrium with the composition of the dissolved phase. Elements present in the 'acido-soluble' fraction are very sensitive to $\mathrm{pH}$ variations, whereas elements scavenged in the reducible or oxidable fractions are very sensitive to redox conditions and to microbiological activity.

The major problems linked to sequential extraction procedure are the lack of selectivity and of efficiency of each step of the procedure (Forstner and Kersten, 1988; Nirel and Morel, 1990; Kheboian and Bauer, 1987; Kersten and Forstner, 1989). Especially the efficiency of the acido-soluble extraction was controversed. It is why the previous study (Leleyter and Probst, 1999) has been now completed in order to show that this fraction is actually essentially composed of carbonates (as calcite or dolomite), whereas phosphates (as apatites) are few solubilized during this extraction step.

\section{Materials and Methods}

All the samples were leached by an optimized chemical extraction procedure (Table 1; Leleyter and Probst, 1999). This procedure dissolves selectively and efficiently all the chemical constituents of the river sediments and soils (Leleyter and Probst, 1999; Aubert et al., 2004) which can be affected by changes in physico-chemical conditions, in the following order: elements dissolved by water (F1), really exchangeable elements (F2), elements bound to acido-soluble fraction (F3), reducible fraction (manganese oxides (F4a), amorphous iron oxides (F4b) and crystalline iron oxides (F4c)) and oxidable fraction (F5) which represents sulfides and organic materials. The Non-Residual Fraction (NRF) or "labile fraction" of the studied sample is the sum of all the previous leached fractions.

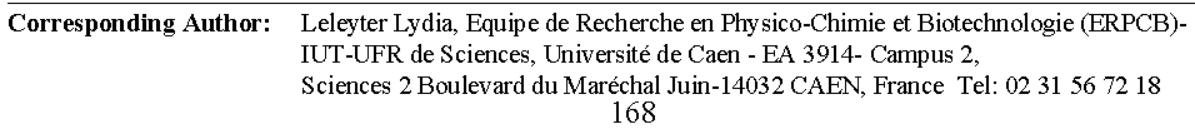


Table 1: Protocol of the 7-steps sequential extraction procedure (Leleyter and Probst, 1999)

\begin{tabular}{|c|c|c|c|c|}
\hline & Fractions & Reagent & Time & $\mathrm{pH}$ \\
\hline $\mathrm{F} 1$ & Evaporitic & $\mathrm{H}_{2} \mathrm{O}$ & $30 \mathrm{~min}$ & 5.7 \\
\hline $\mathrm{F} 2$ & exchangeable & $1 \mathrm{M} \mathrm{Mg}\left(\mathrm{NO}_{3}\right)_{2}$ & $2 \mathrm{~h}$ & 5.0 \\
\hline $\mathrm{F} 3$ & Acido-soluble & $1 \mathrm{MNaOAc} / \mathrm{HOAc}$ & $5 \mathrm{~h}$ & 4.5 \\
\hline $\mathrm{F} 4 \mathrm{a}$ & Reducible (Mn) & $0.1 \mathrm{M} \mathrm{NH}_{2} \mathrm{OH} \mathrm{HCl}$ & $30 \mathrm{~min}$ & 3.5 \\
\hline $\mathrm{F} 4 \mathrm{~b}$ & Reducible (Afe) & $0.2 \mathrm{M}\left(\mathrm{NH}_{4}\right)_{2} \mathrm{C}_{2} \mathrm{O}_{4}$ & & \\
\hline $\mathrm{F} 4 \mathrm{c}$ & Reducible (Cfe) & $\begin{array}{l}+0.2 \mathrm{M} \mathrm{H}_{2} \mathrm{C}_{2} \mathrm{O}_{4} \\
0.2 \mathrm{M}\left(\mathrm{NH}_{4}\right)_{2} \mathrm{C}_{2} \mathrm{O}_{4} \\
+0.2 \mathrm{M} \mathrm{H}_{2} \mathrm{C}_{2} \mathrm{O}_{4}\end{array}$ & $4 \mathrm{~h}$ & 3.0 \\
\hline F5 & Oxidable & $\begin{array}{l}+0.1 \mathrm{M} \mathrm{C}_{6} \mathrm{H}_{8} \mathrm{O}_{6} \\
35 \% \mathrm{H}_{2} \mathrm{O}_{2} / \mathrm{HNO}_{3} \\
\text { then } 3.2 \mathrm{M} \mathrm{NH}_{4} \mathrm{OAc}\end{array}$ & $\begin{array}{l}30 \mathrm{~min} \\
5 \mathrm{~h}\end{array}$ & 2.3 \\
\hline
\end{tabular}

\section{Results and Discussion}

Selectivity of the Sequential Extraction Procedure Used

Several tests on pure natural and synthetic minerals (such as clay minerals, calcite, dolomite, Mn-Oxides, Fe-Oxides and organic matter) have allowed to verify the repeatability, selectivity and efficiency of the used procedure (Leleyter and Probst, 1999).

\section{Efficiency and Selectivity of the Acido-soluble Fraction}

By using the chemical extraction procedure proposed by Leleyter and Probst (1999), Aubert et al. (2004) suggested that phosphate minerals like apatite were dissolved during the acidosoluble step, as they find a maximum of $5 \%$ of the total Ca leached from their soils in this step, despite that these samples presented no trace of carbonates.

Previous study (Leleyter and Probst, 1999) already showed that the extractant solution is efficient to dissolve all carbonates present in sediments (if the studied $1 \mathrm{~g}$ sample contain less than $50 \%$ of carbonates). Dolomite could be also solubilized during the sequential extraction procedure too (Fig. 1). Regarding apatite, complementary investigations have been performed to elucidate this point. The results are presented below (Fig. 1). Synthetic apatite (from ACROS Organics, $\mathrm{Ca}_{3}\left(\mathrm{PO}_{4}\right.$ ) 2 ), has been leached by the used 7 -steps procedure. The results obtained suggest that a maximum of $25 \%$ of Ca could be solubilized if the initial sample contains $10 \%$ of apatite. These results indicate that apatite is more stable that carbonates (as dolomite or calcite) but could be partially solubilized during the acido-soluble step of this sequential extractions procedure.

Moreover in order to study the selectivity of the acido-soluble step, we also investigated apatite stability during the 7 steps sequential extraction procedure (Table 2). The low percentage of $\mathrm{Ca}$ measured in the leachates indicate that apatites are stable during these extractions (except the acidosoluble fraction).

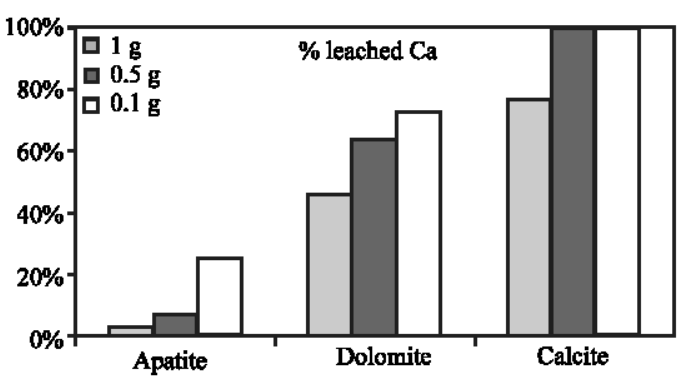

Fig. 1: Efficiency of carbonate dissolution with $10 \mathrm{~mL}$ of $1 \mathrm{M} \mathrm{NaOAc}$ at $\mathrm{pH}=4.50$ (F3 extraction) versus the initial weight of material 
Table 2: Efficiency of apatite dissolution according to \% leached $\mathrm{Ca}$

\begin{tabular}{lcccccccc}
\hline Fraction & F1 & F2 & F3 & F4a & F4b & F4c & F5 & NRF \\
Apatite $1 \mathrm{~g}$ & 0 & 2 & 3 & 1 & 0 & 0 & 4 & 10 \\
Apatite $0.5 \mathrm{~g}$ & 0 & 3 & 7 & 2 & 0 & 0 & 1 & 13 \\
Apatite $0.1 \mathrm{~g}$ & 1 & 5 & 25 & 8 & 0 & 0 & 4 & 43 \\
\hline
\end{tabular}

\section{Conclusions}

This study shows that the acido-soluble fraction is actually essentially composed of carbonates (calcite or dolomite), but that phosphates (as apatites) could also be partially solubilized during this extraction step.

\section{References}

Aubert, D., A. Probst and P. Stille, 2004. Distribution and origin of major and trace elements (particularly REE, $U$ and Th) into labile and residual phases in an acid soil profile (Vosges Mountains, France). Applied Geochem., 19: 899-916.

Baruah, N.K., P. Kotoky, K.G. Bhattacharyya and G.C. Borah, 1996. Metal speciation in Jhanji river sediments. Scien Total Environ., 193: 1-12.

Da Silva, I.S., A. Gilberto, L. Jaim and C.M. Jorge, 2002. Heavy metal distribution in recent sediments of the Tiete-Pinheiros river system in Sao Paulo state, Brazil. Applied Geochem., 17: 105-116.

Forstner, U. and M. Kersten, 1988. Assessment of Metal Mobility in Dredged Material and Mine Waste by Pore Water Chemistry and Solid Speciaton. In: Chemistry and Biology of Solid Waste: Dredged Material and Mine Tailings, Springer-Verlag, Berlin, pp: 214-237.

Gaiero, D.M., J.L. Probst, P.J. Depetris, S. Bidart and L. Leleyter, 2003. Iron and other transition metals in Patagonian riverborne and windborne materials: Their geochemical control and transport to the SW Atlantic ocean. Geochim. Cosmochim. Acta, 67: 3603-3623.

Kheboian, C. and C.F. Bauer, 1987. Accuracy of selective extraction procedures for metal speciation in model aquatic sediments. Anal. Chem., 59: 1417-1423.

Kersten, M. and U. Forstner, 1989. Speciation of Trace Elements in Sediments. In: Trace Element Speciation: Analytical Methods and Problems, CRC Press. Boca, Raton, pp: 245-318.

Lebourg, A., T. Sterckeman, H. Ciesielski and N. Proix, 1996. Intérêt de différents réactifs d'extraction chimique pour l'évaluation de la biodisponibilité des métaux traces du sol. Agronomie, 16: 201-215.

Leleyter, L. and J.L. Probst, 1999. A new sequential extraction procedure for the speciation of particulate trace elements in river sediments. Intl. J. Environ. Anal. Chem., 73: 109-128.

Ma, Y.B. and N.C. Uren, 1998. Transformations of heavy metals added to soil - application of a new sequential extraction procedure. Geoderma, 84: 157-168.

Nirel, P.M.V. and F.M.M. Morel, 1985. Pitfalls of sequential extractions. Water Res., 24: 1055-1056.

Shuman, L.M., 1985. Fractionation method for soil microelements. Soil Science, 140: 11-22.

Tessier, A., P.G.C. Campbell and M. Bisson, 1979. Sequential extraction procedure for speciation of particulate trace metals. Anal. Chem., 51: 844-851.

Ure, A.M., C.M. Davidson and R.P. Thomas, 1995. Single and Sequential Extraction Schemes for Trace Metal Speciation in Soil and Sediment. In: Quality Assurance for Environmental Analysis (BCR), Elsevier, pp: 505-523. 